\title{
PKM Kelompok Budidaya Tanaman Temu-Temuan dan Empon-Empon Untuk Meningkatkan Daya Tahan Tubuh di Masa Pandemi Covid-19
}

\author{
Gusti Ayu Kade Sutariati ${ }^{1 *}$, La Ode Safuan ${ }^{1}$, Siti Leomo ${ }^{2}$, Nini Mila Rahni ${ }^{1}$, \\ Gusti Ngurah Adhi Wibawa ${ }^{3}$ \\ ${ }^{1}$ Jurusan Agroteknologi, Fakultas Pertanian, Universitas Halu Oleo, \\ ${ }^{2}$ JurusanIlmu Tanah, Fakultas Pertanian, Universitas Halu Oleo. \\ ${ }^{3}$ Jurusan Statistik, Fakultas Matematika dan Ilmu Pengetahuan Alam, Universitas Halu Oleo
}

\author{
Article history \\ Received: 27 Mei 2021 \\ Revised: 11 Juni 2021 \\ Accepted: 23 Juni 2021 \\ *Corresponding Author: \\ Gusti Ayu Kade Sutariati, Fakultas \\ Pertanian Universitas Halu Oleo, \\ Indonesia \\ Email: sutariati69@yahoo.co.id
}

Abstract: The development of medicinal plants (herbs) has very promising prospects because they are able to increase the body's resistance to various diseases including viruses. The current condition of the world, which is being hit by the coronavirus disease 2019 (covid-19) pandemic, requires serious attention from all components of society to contribute to the fight against this outbreak. One of them is through the efforts of the community itself in fighting the virus by consuming foods that can increase the body's resistance then that the body remains healthy and strong. Until now, the majority of the community has grown curd and herbs plants only to meet personal needs, even though these types of plants can be developed more broadly on a commercial scale. This community service activity (Internal Community Creativity Program), was aim to helping provide understanding and comprehending to the members of the Dasawisma Mepokoaso Group in Tobimeita Village, Abeli District, Kendari City on the magnitude of the herbal plant benefits which can increase the body's resistance to various infection diseases, including those caused by the Covid-19. The method of activity wass carried out in the form of counseling and technical guidance on the herbs plant cultivation based on environmentally friendly technology. The results shows that the target community was very enthusiastic on participating in this activity, they stated that they would continue the activity independently. There was an increase in the empowerment of the target farmer groups, the existence and sustainability on the agribusiness and cultivating of herb plants which have implications for increasing the income of farmer groups.

Keywords: Covid-19; herbs; creativity; Public; organic

Abstrak: Pengembangan tanaman temu-temuan dan empon-empon organik memiliki prospek yang sangat cerah dan menjanjikan karena terbukti mampu meningkatkan daya tahan tubuh terhadap berbagai penyakit termasuk virus. Kondisi dunia saat ini yang tengah dilanda pandemi coronavirus disease 2019 (covid-19), memerlukan perhatian serius dari semua komponen masyarakat untuk ikut berkontribusi dalam memerangi wabah ini. Salah satunya adalah melalui upaya masyarakat itu sendiri dalam memerangi virus dengan mengkonsumsi makanan yang dapat meningkatkan daya tahan tubuh sehingga tubuh tetap sehat dan kuat. Sampai saat ini, sebagian besar masyarakat menanam tanaman temu-temuan dan empon-empon terbatas hanya untuk memenuhi kebutuhan pribadi, padahal jenis tanaman ini dapat dikembangkan lebih luas dalam skala komersial. Kegiatan pengabdian kepada masyarakat (Program Kreativitas Masyarakat Internal) ini, dilaksanakan dengan tujuan membantu memberikan pengertian dan pemahaman kepada ibu-ibu Anggota Kelompok Dasawisma Mepokoaso di Kelurahan Tobimeita Kecamatan Abeli Kota Kendari tentang besarnya manfaat tanaman herbal ini yang dapat meningkatkan daya tahan tubuh terhadap berbagai infeksi penyakit termasuk yang disebabkan oleh virus Covid-19. Metode kegiatan dilaksanakan dalam bentuk penyuluhan dan bimbingan teknis budidaya tanaman temu-temuan dan empon-empon berbasis teknologi ramah lingkungan. Hasilnya menunjukkan bahwa masyarakat sasaran sangat antusias mengikuti kegiatan ini, mereka 
menyatakan akan meneruskan kegiatan secara mandiri. Ada peningkatan keberdayaan kelompok tani sasaran, eksistensi dan keberlanjutan usaha agribisnis tanaman temu-temuan dan empon-empon organik yang berimplikasi pada peningkatan pendapatan kelompok tani sasaran.

Kata kunci: Covid-19; herbal; kreativitas; masyarakat; organik

\section{PENDAHULUAN}

Kelurahan Tobimeita terletak di Kecamatan Abeli Kota Kendari Provinsi Sulawesi Tenggara. Jarak dari kelurahan ini ke pusat Kota Kendari mencapai $+20 \mathrm{~km}$. Perekonomian masyarakat di kelurahan ini bersumber dari sektor pertanian (tanaman pangan), perkebunan, kehutanan, peternakan dan perikanan, di samping pekerjaan lainya sebagai buruh angkut, PNS, pedagang, bidang jasa, TNI/POLRI dan usaha produktif lainnya. Lahan pertanian seluas $170 \mathrm{Ha}$, umumnya ditanami palawija dan sayuran. Sementara itu lahan perkebunan seluas $210 \mathrm{Ha}$ ditanami dengan komoditas perkebunan utama yaitu jambu mete $( \pm 100 \mathrm{Ha})$, lada $( \pm 20 \mathrm{Ha})$, kelapa, kopi, kakao dan cengkeh.Dibidang kehutanan, Kelurahan Tobimeita memiliki 50 Ha hutan konservasi, 200 Ha hutan lindung dan 100 Ha hutan produksi.

Sehubungan dengan lahan pertanian dan perkebunan demikian luasnya, tentu sangat prospektif untuk pengembangan tanaman temu-temuan dan empon-empon sebagai usaha sampingan yang menjanjikan dan menguntungkan. Apalagi pada masa pandemi covid-19 saat ini, harga tanaman temu-temuan dan empon-empon meningkat tajam, bahkan ketersediaannyapun sangat langka. Jikapun masa pandemi telah berlalu, tanaman temutemuan dan empon-empon akan terus dibutuhkan oleh masyarakat karena pemanfaatannya yang sangat beragam, mulai dari bahan bumbu masakan, obat-obatan dan dapat dikembangkan lebih lanjut menjadi komoditas ekspor. Para petani/masyarakat tidak memerlukan lahan khusus untuk budidaya tanaman ini, karena mereka dapat memanfaatkan ruaang di sela-sela tanaman perkebunan. Jadi tanaman temu-temuan dan empon-empon ini dapat dimanfaatkan sebagai tanaman sela. Selain bernilai ekonomis, tanaman sela ini juga dapat mengurangi biaya yang dikeluarkan petani untuk pembersihan gulma tanaman utama.

Jika ditinjau dari sumberdaya yang dimiliki, kelurahan Tobimeita memiliki potensi yang sangat besar untuk pengembangan tanaman temu-temuan dan empon-empon secara organik. Ketersediaan lahan budidaya yang luas, didukung sumberdaya lain seperti ternak sapi, kambing dan ayam dengan potensi limbah kotoran yang dapat diolah menjadi pupuk organik, jika dikembangkan dan diberdayakan secara terpadu, maka kelurahan Tobimeita dapat menjadi percontohan kelurahan penghasil tanaman temu-temuan dan empon-empon organik di Kecamatan Abeli Kota Kendari. Oleh karena itu melalui Program Kemitraan Masyarakat (PKMI) ini diharapkan dapat membantu memberikan pemahaman kepada masyarakat sasaran tentang pentingnya membudidayakan tanaman terutama temu-temuan dan empon-empon secara organik melalui pemanfaatan sumberdaya lokal.

Teknologi yang akan diimplementasikan dalam kegiatan PKMI ini adalah teknologi tepat guna ramah lingkungan berbasis LEISA (Low External Input Sustainable Agriculture), yang memprioritaskan pada pemanfaatan sumberdaya lokal dalam proses budidaya tanaman temu-temuan dan empon-empon. Teknologi 
budidaya yang digunakan bersifat hayati/alami melalui pemanfaatan bahan organik sekitar tanpa aplikasi pestisida kimiawi, sehingga produk yang dihasilkan lebih sehat dan bebas racun (Shedeed et al., 2014; Patil et al., 2015; Ahemad and Kibret, 2016; Ceglie et al., 2016; Gupta et al., 2015). Teknologi LEISA ini diintegrasikan dengan teknik invigorasi benih untuk meningkatkan vigor tanaman dan mengatasi rendahnya produktivitas yang disebabkan penggunaan benih bervigor rendah. Teknik ini terbukti efektif meningkatkan viabilitas dan vigor benih (Sutariati et al., 2013; Ilyas et al.2015).

Teknik invigorasi benih juga diinkorporasikan dengan mikroba dari kelompok bakteri seperti Bacillus spp, Pseudomonas fluorescens dan Serratia spp. yang mampu dan efektif mengendalikan penyakit tanaman (Suman et al., 2016; Agbodjato et al., 2015). Proses pengendalian dilakukan melalui mekanisme kompetisi, antibiosis, siderofor, hidrogensianida dan eksresi enzim hidrolitik yang berfungsi sebagai senyawa anti-mikrob (Aulakh and Ravisankar, 2017. Melalui aplikasi teknologi ramah lingkungan (produk pupuk organik plus), diharapkan kegiatan ini akan dapat dilaksanakan secara efektif dan efisien serta dapat memberikan manfaat yang sebesar-besarnya bagi pengembangan usaha ekonomi kreatif sehingga menjadi kelompok usaha yang lebih maju.

\section{METODE}

Sebagaimana dijelaskan sebelumnya, Mitra kegiatan PKMI ini Kelompok Dasawisma Mepokoaso. Target penyelesaian masalah di ke-2 kelompok tani sasaran ini adalah kemampuan target mengaplikasikan teknologi budidaya temu-temuan dan empon-empon secara organik dan kemampuan target membuat sendiri pupuk organik melalui pemanfaatan limbah yang tersedia di sekitarnya. Teknologi yang akan diimplementasikan tidak hanya pada skala proses produksi, namun sampai pada teknologi pascapanen, pemasaran, bahkan analisis ekonomi produk (manajemen usaha), sehingga dapat digunakan sebagai acuan bagi mereka dalam melakukan berbagai alternatif usaha di masa-masa yang akan datang. Metode pendekatan yang digunakan dalam kegiatan ini adalah penyuluhan, pelatihan dan bimbingan teknis serta pendampingan teknologi melalui pembuatan demplot budidaya temu-temuan dan empon-empon organik secara langsung kepada Mitra sasaran.

Prosedur kerja dan strategi kegiatan pengabdian kepada masyarakat melalui program PKMI ini, serta keterlibatan Mitra dalam setiap tahapan kegiatan dilaksanakan sebagai berikut:

1. Persiapan kegiatan (peninjauan lokasi, diskusi dan konsultasi terkait rencana kegiatan bersama Mitra).

2. Penyuluhan teknik budidaya tanaman temu-temuan dan empon-empon organik berbasis pemanfaatan mikroba lokal dalam bentuk pupuk organik plus.

3. Penyuluhan tentang potensi dan peluang produk tanaman temu-temuan dan empon-empon organik sebagai bagian dari ekonomi kreatif melalui berbagai inovasi teknologi produksi dan pengolahan pasca panen, peluang pasar lokal dan nasional, dan prospek agribisnis berdasarkan analisis ekonomi terhadap produk yang diusahakan. 
4. Bimbingan teknis dan pendampingan secara langsung kepada Mitra sasaran terkait teknik budidaya tanaman temu-temuan dan empon-empon organik termasuk pemeliharaan, produksi sampai panen, pasca panen dan pengolahan pasca panen.

5. Bimbingan teknis dan pendampingan secara langsung pembuatan pupuk oganik menggunakan mikroba dan bahan-bahan organik dari sumberdaya lokal.

Mitra sasaran (Kelompok Dasawisma Mepokoaso) sebagai pengadopsi dan pengguna teknologi selanjutnya terlibat secara langsung dalam setiap tahapan kegiatan, sehingga pemahaman dan implikasi teknologi dapat ditularkan secara lebih komprehensif dan aplikasi inovasi teknologi di tingkat pengguna (sasaran) pada akhirnya dapat dilaksanakan secara berkelanjutan. Di samping itu diharapkan mereka dapat menularkan setiap ilmu dan keterampilan yang dimiliki kepada anggota-anggota lainnya atau masyarakat sekitarnya, sehingga semakin banyak masyarakat yang dapat mengambil manfaat dari kegiatan PKMI ini.

\section{HASIL DAN PEMBAHASAN}

Wilayah pemerintahan Kelurahan Tobimeita yang terletak cukup dekat dengan pusat kota Kendari, memiliki potensi cukup besar dalam pengembangan sistem budidaya tanaman temu-temuan dan empon-empon secara organik. Lingkungan pemukiman tidak terlalu padat, dengan pekarangan cukup luas, sehingga sangat memungkinkan bagi para ibu rumah tangga untuk menanam tanaman temu-temuan dan empon-empon yang dibudidayakan secara organik. Lokasi kegiatan pengabdian masyarakat ini dilaksanakan di areal kantor lurah, sehingga mudah diakses oleh warga masyarakat.

Pada saat pelaksanaan kegiatan penyuluhan, warga masyarakat sangat responsif dan menunjukan antusiasme yang tinggi terhadap materi penyuluhan yang diberikan. Keseriusan yang ditunjukkan oleh mereka Nampak dari banyaknya pertanyaan yang disampaikan oleh mereka kepada tim pengabdian masyarakat. Berdasarkan hasil diskusi tersebut dapat dijelaskan bahwa pada umumnya peserta target sangat berkeinginan untuk dapat mengimplementasikan teknik budidaya tanaman temu-temuan dan empon-empon yang telah diberikan, karena sangat bermanfaat baik untuk konsumsi keluarga, maupun untuk menambah penghasilan dan perekonomian keluarga. Kenyataan yang mereka hadapi adalah peningkatan penggunaan pupuk dan pestisida kimiawi tidak mampu meningkatkan produktivitas usaha tani mereka, karena justru tanaman mereka semakin banyak diserang hama dan penyakit. 


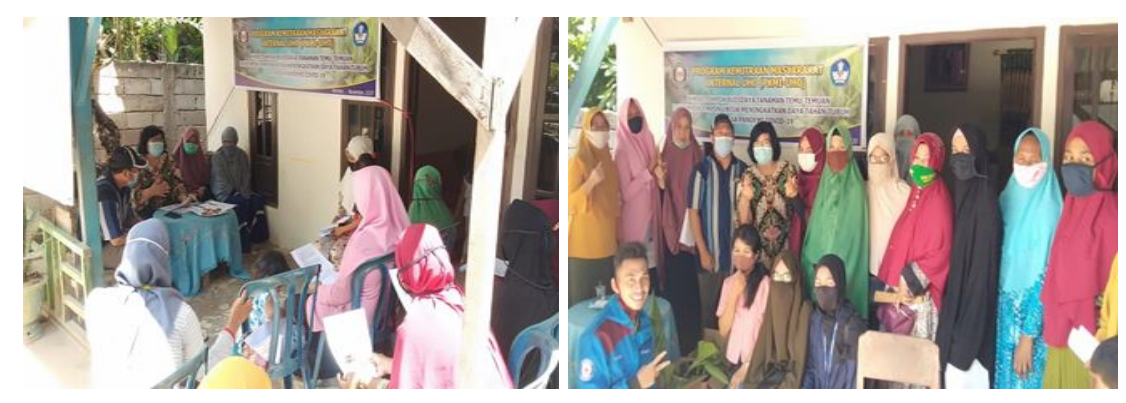

Gambar 1.

Pelaksana kegiatan pengabdian kepada masyarakat yang mengikut sertakan mahasiswa Fakultas Pertanian UHO

Teknologi yang diaplikasikan dalam kegiatan ini merupakan teknologi ramah lingkungan yang memanfaatkan penggunaan bahan-bahan organik sebagai sumber bahan pembuatan pupuk organik plus. Namun demikian dalam proses pembuatan pupuk organik, bahan organik diperkaya dengan mikroba lokal yang telah terbukti mampu berperan sebagai biofertilizer dan bioprotektan. Kegiatan pengabdian kepada masyarakat ini menunjukkan hasil yang sangat baik dan mendapat apresiasi positif dari para peserta. Transfer informasi dan teknologi merupakan metode yang sangat tepat dan efisien untuk bekal pembelajaran bagi peserta target, sehingga pengetahuan yang diberikan melalui kegiatan penyuluhan tidak hanya sekedar dipahami sementara, namun dapat dipahami sepenuhnya sehingga mereka secara langsung dapat mengaplikasikan teknologi tersebut.

Faktor-faktor yang dapat dianggap sebagai pendukung kegiatan pengabdian ini adalah:

1. Peserta dan masyarakat sekitarterhadap materi penyuluhan yang diberikan sangatpositif, bahkan mereka mengharapkan kegiatan pengabdian masyarakat ini dapat dilaksanakan secara berkelanjutan. Kurangnya pengetahuan mereka tentang sumber daya alam sekitar terutana tanaman temu-temuan dan empon-empon yang dapat dimanfaatkan sebagai sumber bahan pembuatan minuman yang menyehatkan dan meningkatkan imun tubuh, menyebabkan mereka ragu untuk mengkonsumsi bahan tersebut. Di samping itu, para peserta sangat mengharapkan bimbingan secara khusus untuk penerapan teknologi budidaya secaraorganik dalam pengembangan tanaman tersebut di wilayah mereka. Hal ini merupakan modal utama bagi tim untuk melakukan kegiatan-kegiatan lanjutan pada masa-masa yang akan datang.

2. Lokasi kegiatan yang memiliki potensi untuk pengembangan tanaman temu-temuan dan empon-empon membuat para peserta semakin bersemangat untuk melaksanakan kegiatan lanjutan, dengan harapan Kelurahan Tobimeita dapat menjadi salah satu sentra produksi tanaman temu-temuan dan empon-empon di Sulawesi Tenggara.

3. Teknologi yang diimplementasikan dalam proses produksi tanaman temu-temuan dan empon-empon secara organik, merupakan teknologi ramah lingkungan berbasis LEISA (Low External Input Sustainable Agriculture), yang mengkombinasikan teknologi pemanfaatan sumberdaya hayati indigenus Sulawesi Tenggara tanpa aplikasi pestisida kimiawi, sehingga produk yang dihasilkan lebih sehat dan bebas racun (Sutariati et al., 2013). Teknologi LEISA ini diintegrasikan dengan teknik invigorasi benih untuk meningkatkan vigor tanaman. Teknik 
ini terbukti efektif meningkatkan viabilitas dan vigor benih berdasarkan hasil-hasil penelitian sebelumnya (Ilyas et al. 2015; Sutariati et al., 2016; Sutariati et al., 2018a, b, c; Sutariati et al., 2020).

4. Teknik invigorasi benih juga diinkorporasikan dengan mikroorganisme dari kelompok bakteri sepertiBacillus spp., Pseudomonas fluorescensdanSerratia spp. yang mampudan efektif mengendalikan penyakit tanaman (Sutariati et al., 2018a). Proses pengendalian dilakukan melalui mekanisme kompetisi, antibiosis, siderofor, hidrogen sianida dan eksresienzim hidrolitik yang berfungsi sebagai senyawa anti-mikrob. Di sampingitu agensia hayati juga dapat mengkelat unsur penting dari daerah sekitar perakaran tanaman sehingga dapat dimanfaatkan oleh tanaman. Bacillus spp., P. fluorescens dan Serratia spp. Juga mampu mensintesis hormon tumbuh, memfiksasi nitrogen atau melarutkan fosfat (Sutariati et al., 2018 b,c).

5. Melalui aplikasi teknologiramah lingkungan (produk pupuk organik plus), diharapkan kegiatan Pengabdian Masyarakat ini dapat dilaksanakan secara efektif dan efisien serta dapat memberikan manfaat yang sebesarbesarnya bagi masyarakat Kelurahan Tobimeita.

\section{KESIMPULAN DAN SARAN}

Masyarakat sasaran (Kelompok Dasawisma Mepokoaso) dan masyarakat sekitar lokasi pengabdian sangat antusias dan aktif berpartisipasi dalam kegiatan penyuluhan dan pendampingn budidaya tanaman temu-temuan dan empon-empon secara organik yang diberikan. Target dan masyarakat setempat mengharapkan kesediaan tim pengabdian masyarakat untuk memberikan bimbingan teknis lanjutan teknologi pengembangan dan pemanfaatan tanaman temu-temuan dan empon-empon sebagai produk hasil olahan (berbentuk minuman sehat/jamu) yang memiliki nilai ekonomis lebih tinggi untuk memenuhi kebutuhan masyarakat secara umum.

Sebagai saran dalam pelaksanaan kegiatan pengabdian kepada masyarakat pada masa mendatang perlu dilakukan kerjasama yang lebih intensif dengan instansi pemerintah setempat terutama Dinas Pertanian/Perkebunan atau instansi lain yang terkait.

\section{Ucapan Terima Kasih}

Penulis mengucapkan terima kasih kepada Rektor Universitas Halu Oleo melalui Ketua Lembaga Penelitian dan Pengabdian kepada Masyarakat yang telah member dukungan financial terhadap kegiatan pengabdian kepada masyarakat ini melalui skim Program Kemitraan Masyarakat Internal (PKMI) UHO tahun anggaran 2020.

\section{Daftar Pustaka}

Agbodjato, N.A, Noumavo. P.A, Adjanohoun, A, Agbessi, L, and Moussa, L.B. 2015. Synergistic Effects of Plant Growth Promoting Rhizobacteria and Chitosan on In Vitro Seeds Germination, Greenhouse Growth, and Nutrient Uptake of Maize (Zea mays L.). Biotechnology Research International Volume 2016. http://dx.doi.org/10.1155/2016/7830182. [Diakses 6 Juni 2019]. 
Ahemad and Kibret, M. 2016. Mechanisms and applications of plant growth promoting rhizobacteria: Current perspective Munees. Journal of King Saud University - Science 26: 1-20.

Aulakh and Ravisankar, N. 2017. Organic Farming in Indian Context: A Perspective. Agric Res J 54 (2) : 149-164.

Ceglie, F.G, Amodio, M.L and Colelli, G. 2016. Effect of Organic Production Systems on Quality and Postharvest Performance of Horticultural Produce. Horticulturae 2 (4): 1-7.

Gupta, G, Parihar, S.S, Ahirwar, N.H, Snehi, S.K and Singh, V. 2015. Plant Growth Promoting Rhizobacteria (PGPR): Current and Future Prospects for Development of Sustainable Agriculture. Microbial \& Biochemical Technology 7(2): 096-102.

Ilyas, S, Asie, K.Vand Sutariati, G.A.K. 2015.Biomatriconditioning or biopriming with biofungicides or biological agents applied on hot pepper (Capsicum annuum L.) seeds reduced seedborne Colletotrichumcapsici and increased seed quality and yield. ISHS Acta Horticulturae 1105: 89-96.

Patil,P, Ghag, P andPatil, S. 2015. Use of Bio-fertilizers and Organic Inputs - as LISA technology by farmers of Sangamner.International Journal of Advancements in Research \&Technology2(7): 28-33.

Shedeed, S.I, EL-Sayed,S.A.A andBash,D.M.A. 2014.Effectiveness of bio-fertilizers with organic matter on the growth, yield and nutrient content of Onion (Allium cepa L.) plants.European International Journal of Science and Technology3(9): 115-122.

Suman, B, Gopal, A.V, Reddy, R.S andTriveni, S. 2016. Isolation and Characterization of Pseudomonasfluorescens in the rice rhizospheric soils ofRangareddy district in Telangana state. International Journal of Microbiology Research and Reviews 5 (1): 164-169.

Sutariati, G.A.K, Khaeruni,A, Pasolon, Y.B, Muhidin andMudi, L. 2016. The Effect of Seed Bio-invigoration Using Indigenous Rhizobacteria to Improve Viability and Vigor of Upland Rice (Oryza sativa L.)Seeds.International Journal of PharmTech Research9 (12): 565-573.

Sutariati, G.A.K, Rakian, T.C, Khaeruni, A and Ratna. 2018a. The potential of indigenous rhizobacteria isolated from wakatobi rocky soil as plant growth promoting of onions.Biosci. Res. 15: 3755-3761.

Sutariati, G.A.K, Jusoff, K, Gusti Ray, S.I, Khaeruni, A, Muhidin and Meisanti 2013. Effectiveness of bioinvigoration technologies on seed viability and vigor of cocoa (Theobroma cacaoL.). World Appl. Sci. J. 26: 3-6.

Sutariati, G.A.K, Muhidin, Rakian, T.C, Afa, L.O, Widanta, I.M, Mudi, L, Sadimantara, G.R and Leomo, S. 2018 b. The effect of integrated application of pre-plant seed bio-invigoration, organic and inorganic fertilizer on the growth and yield of local upland rice.Biosci. Res. 15: 160-165.

Sutariati, G.A.K, Bande, L.O.S, Khaeruni, A, Muhidin, Mudi, L and Savitri, R.M. 2018c. The effectiveness of preplant seed bio-invigoration techniques using Bacillus sp. CKD061 to improving seed viability and vigor of several local upland rice cultivars of Southeast Sulawesi.IOP Conf. Ser. Earth Environ. Sci. 122

Sutariati, G.A., K, Rahni, N.M, Madiki, A, Mudi, L, Guyasa, I.M and Zahrima, 2020 Characterization of endophytic-rhizobacteria from areca nut rhizosphere to dissolve phosphates, nitrogen fixation of iaa hormone synthesis.Pakistan J. Biol. Sci. 23(3): 240-247. 